\title{
Aesthetics of Modern Architecture: A Semiological Survey on the Aesthetic Contribution of Modern Architecture
}

\author{
Hourakhsh Ahmad Nia", Rokhsaneh Rahbarianyazd \\ Department of Architecture, Faculty of Architecture, Alanya Hamd Emin Paşa University, Turkey \\ Received November 21, 2019; Revised January 21, 2020; Accepted February 18, 2020
}

Copyright $\bigcirc 2020$ by authors, all rights reserved. Authors agree that this article remains permanently open access under the terms of the Creative Commons Attribution License 4.0 International License

\begin{abstract}
Starting from the Industrial Revolution, continuous technical progress in Modern Architecture introduced new dimensions to the traditional methods of construction. Thus, Modern Architecture had a tremendous effect in introducing new approaches to the aesthetic understanding of the built environment. In addition, there are a lot of criticism on the philosophy of Modern Architecture and the idea of Machine Age Architecture led to the lack of sense of place and cultural detachment. This study aimed to assess the existing gap in literature by using a qualitative assessment of literature on Modern Architecture and stylistic classification of architectural movements in the Modern era. Overall, the study concludes that ignoring cultural values and its semiological references in architectural design are the most important aesthetic factor that led to the failure of Modern Architecture.
\end{abstract}

Keywords Modern Architecture, Aesthetic Contribution, Semiological Survey, Stylistic Classification

\section{Introduction}

The birth of Modern Architecture was perceived to begin with the 19th century along with the industrial revolution and the concomitant introduction of mass production which stirred a general detestation of historicism, interest in functionalist planning, the use of modern building materials and existing new technologies (Ali, 2018; Arenibafo, 2018). Considering this fact, Modern Architecture is characterized by simple rectilinear shapes, plain undecorated walls, bald facades and often times, dull colors using simple elementary shapes, lines, and forms as basis for design. Modern Architecture is celebrated for architectural milestone because it provided the template that easily detached from the historical umbilical cord and permanently changing the traditional and future course of architectural discuss. All of these brought along with it, radical urban changes (owing to the new technologies), which further affected radical aesthetic changes and a new concept of the construction (Amiri, 2016).

Apart from positive contributions of Modern architecture, it can be seen that there are many criticisms on Modern Architecture. The first of these was Robert Venturi in his book: "Complexity and Contradiction in Architecture" revealed that the modern architecture of the 1960s according to Nesbitt (1996) "had been reduced to formulaic repetition of canonical works of the Modern Movement, to technological utopias, and to expressionist fantasies". Robert Venturi's maxim that "less is bore" was a bold declaration premised of a pluralistic and multi-dimensional approach that redirected from the reductivist school of the Modern Movement.

According to Tadao Ando, Modern Architecture is an attempt to solve real life problems by numbers and measurable standards (Ando, 1993:7) and as a result, the "make-up" and mythical aspects of architecture are ignored. Hence, Ando considers that most often than none, the products of Modern Architecture have no stories to tell, but are simply purely functional and without messages that stirs our fascination. It just exists without provoking the audience (Ando, 2002). Against this backdrop, Norberg-Schulz argued that from ab-initio, Modern Architecture was not meant to have a regional character but sought to be an "international" language (Norberg-Schulz, 1988:135). This led to the problem of "loss of place", loss of the character of places and overall loss of place identity. Considering the above-which somehow reveals the non-aesthetic quality of Modern Architecture, this study by qualitative assessment of literature on the philosophy of Modern Architecture, aimed to examine the main indicators shaping the aesthetic quality 
of modern architecture and to classify them into specific aesthetic characteristics. These specific characteristics are highlighted as architectural styles of Modern Architecture.

\section{Materials and Methods}

\subsection{Modern Architecture as a Style}

As earlier stated, Modernist Architecture (or simply stated- Modernism) emerged in the early-20th century as answer to enormous changes in both society and technology. It was associated with functionalist rationalism, the abhorrence of ornaments, analytical viewpoints and a rational use of materials. It took roots in Europe and in particular, the German school of Architecture- the Bauhaus. The Bauhaus made important contributions, such as "less is more" (Frampton, 1992) in the evolution Modern Architecture. The school was however brought under strong Nazi persecution and as a result, immigrated to the United States. Consequent upon which Modern Architecture also travelled along with it. In the United States, the influence of Modern Architecture became more legible and it was renamed "the International Style". The International Style projected similar characteristics to the Modern Movement such as beige and clinical white colored buildings, weightlessness, disdain of ornamentation and the rejection of tradition (Salvo, 2015; Jaff et all, 2017).

Modern Architecture simply defined is the abstraction of basic forms, shapes and lines to create clean and simple undecorated rectilinear forms. Needless saying that its aesthetic language is conveyed by fundamentally simple geometric forms such as rectangles and squares. The maxims: 'form follows function', 'fitness for purpose' are all inextricably interwoven with Modern Architecture. Thus, Modern Architecture is primarily concerned with the functionality of spaces and its form derives from this. Several architects have their own maxims defining their philosophy of architecture. The following table illustrates the famous maxims (and their period in time) peculiar to certain famous architects.

As can be seen, the most noticeable buildings of Modern Architecture which are mentioned in Table 1 are the results of developments in technologies and have developed its own specific aesthetic characteristics. This study, by qualitative analysis of the philosophy of Modern Architecture and critical analysis of existing literature, illustrates the main aesthetic characteristics of the Modern Architecture.

Main protagonist often associated with the development of High Modernism were Walter Gropius, Le Corbusier and Ludwig Mies van der Rohe and Adolf Loos.

\subsubsection{Walter Gropius and the Beginning of Modern Architecture}

In Germany, Modernism is akin to the Bauhaus. The Bauhaus was founded by Walter Gropius in 1919. It sought to integrate scholarship (pure arts) with crafts and this brought new insights to art training (Aziz Amen, 2017). Gropius was a visionary and his aim was to harmonize technology and arts consequent upon which he trained a new generation of designers and architects to reject historicism and accept the new dogma - the Modern Movement. In the overall, Gropius largely re-discovered the tenets of Modern Architecture which developed into the international style (Frampton and Futagawa, 1983). The suspended glass wall provided a clear case in point. Instead of being set back from the supporting columns of the building, it was suspended outside the columns enabling a lucid display its non-structural function.

\subsubsection{Le Corbusier's and the Notion of Machine Aesthetics}

Le Corbusier's popular maxim, 'the house is a machine for living' showed that machine aesthetic is an important concept for functionality, standardization and rationalism that altogether underpinned the idea of Modern Architecture (Le Corbusier, 1986). This maxim meant that a house is conceptually analogous to a machine and as such, should be built the same way a machine (such as a car) was fabricated. This led to the notion of standardization, implying the production of standardized prototypes for construction. Edward Jeanerette (as Le Corbusier was also called) further extended this idea to city scale (Evenson, 1969). The idea also led to the introduction of logic, scholarship and systemic reasoning as the basis for architectural designs and further provided ways that systematize the relationship between man and the living space. 'The key modern principle for Le Corbusier was function, and this is where the machine metaphor is so important' (Le Corbusier, 1986). To state it succinctly in summing-up, Le Corbusier's emphasis if anything was that standardization is the key to Architecture fulfilling its functions.

\subsubsection{Mies van der Rohe}

A major actor in the realization of the International style was Mies van der Rohe. Along with Walter Gropius and Le Corbusier in the early 1920s, he reinforced the notion of the International Style as the core movement of Modern Architecture. Mies advocated the Minimalist Architecture through the minimal use of space, curtain wall, columns and beams and sparing use of industrial materials. $\mathrm{He}$ metaphorically denoted that the rigid columns and beams are bones while the cladding is the skin; thus his well-known maxim: "skin-and-bones". Mies's encouraged maximum flexibility of spatial layout, which according to him represents maximum spatial utility. His steel-and-glass aesthetic became a template for Modern Architecture for decades even after his death. Meanwhile, his designs have always expressed practical aesthetic- a beauty that serves its inhabitants. 
Table 1. Famous maxims in Modern Architecture that affected the development of modern aesthetics

\begin{tabular}{|c|c|c|c|c|}
\hline Theoretician & Motto & $\begin{array}{l}\text { Name Of The Building Designed based } \\
\text { on this Theory }\end{array}$ & Architect & $\begin{array}{c}\text { Date Of } \\
\text { Construction }\end{array}$ \\
\hline $\begin{array}{l}\text { Adolf Loos } \\
1870-1933\end{array}$ & "Ornamentations is Crime." & Steiner House & Adolf Loos & 1910 \\
\hline $\begin{array}{c}\text { Louis Sullivan } \\
1856-1924\end{array}$ & "Form Follows Function." & Bauhaus school & Walter Gropius & 1926 \\
\hline $\begin{array}{c}\text { Le Corbusier } \\
1887-1965\end{array}$ & $\begin{array}{c}\text { "A house is a machine for } \\
\text { living in." }\end{array}$ & Villa Savoye & Le Corbusier & 1929-1931 \\
\hline \multirow{2}{*}{$\begin{array}{l}\text { Mies van der } \\
\text { Rohe } \\
1886-1969\end{array}$} & "Less is more." & Glass House & Philip Johnson & 1949 \\
\hline & "God is in the details." & Seagram Building & $\begin{array}{l}\text { Mies van der } \\
\text { Rohe }\end{array}$ & 1958 \\
\hline $\begin{array}{c}\text { Frank Lloyd } \\
\text { Wright } \\
1867-1959 \\
\end{array}$ & $\begin{array}{l}\text { "An idea is salvation by } \\
\text { imagination" }\end{array}$ & Falling Water & $\begin{array}{l}\text { Frank Lloyd } \\
\text { Wright }\end{array}$ & 1936-1939 \\
\hline
\end{tabular}

Table 2. Aesthetic characteristics, implementing ideas and philosophy of Modern Architecture

\begin{tabular}{|c|c|c|}
\hline Implementing Ideas & Philosophy & Architectural Characteristic \\
\hline $\begin{array}{l}\text {-Standardization of Architecture. } \\
\text {-Rational order. }\end{array}$ & $\begin{array}{l}\text {-Machine age Aesthetics. } \\
\text {-Scientific and logical reasoning. } \\
\text {-Architectural system for human } \\
\text { well-being. }\end{array}$ & $\begin{array}{c}\text {-Structural Possibilities. } \\
\text {-Open plan design. } \\
\text { - Large windows and open floor plans. } \\
\text {-Simple shapes. }\end{array}$ \\
\hline - Standardization & -Need for Mass housing. & $\begin{array}{l}\text {-Five points of architecture. } \\
\text {-Pre-Fabrication }\end{array}$ \\
\hline $\begin{array}{c}\text {-Simplified Forms } \\
\text {-Functional forms } \\
\text {-Based on Kant's theory of form. }\end{array}$ & $\begin{array}{c}\text {-Abstraction } \\
\text {-Clean Aesthetic }\end{array}$ & $\begin{array}{l}\text {-Box-like building. } \\
\text {-Cubic volume, a flat roof. } \\
\text {-Clean lines. }\end{array}$ \\
\hline -Functionality and Open Floor Plan. & $\begin{array}{l}\text {-Functional design } \\
\text {-Transparency }\end{array}$ & $\begin{array}{l}\text {-Uses and Benefits of Glass } \\
\text { - Dom-Ino House }\end{array}$ \\
\hline -Rejection of traditional styles. & -Ornamentation is crime. & $\begin{array}{l}\text {-Simple forms with no } \\
\text { ornamentations. }\end{array}$ \\
\hline $\begin{array}{l}\text { - Rectangular Forms. } \\
\text {-Horizontal and Vertical Lines. }\end{array}$ & $\begin{array}{l}\text {-Juxtapose against the horizontal } \\
\text { elements. }\end{array}$ & $\begin{array}{l}\text {-Materials in good distinct planes. } \\
\text { - Materials give a intense effect. }\end{array}$ \\
\hline -Low, Horizontal Massing. & -Horizontal Planes & -Flat Roofs \\
\hline -Concrete & $\begin{array}{l}\text {-Highlighting the honesty of Materials. } \\
\text {-Stained and exposed materials. }\end{array}$ & $\begin{array}{l}\text {-Open column free spaces. } \\
\text {-Domino Houses }\end{array}$ \\
\hline $\begin{array}{l}\text {-Maximize the entry of light into a } \\
\text { building. } \\
\text { - CIAM approaches . }\end{array}$ & $\begin{array}{l}\text {-Increasing the quality of life. } \\
\text {-The necessity of using natural light in } \\
\text { design. } \\
\text {-Promote human comfort and health. }\end{array}$ & $\begin{array}{l}\text {-Large glass windows from ceiling to } \\
\text { floor. } \\
\text {-Façade steel frame construction. } \\
\text {-Five points of architecture. } \\
\text {-Fully glazed exterior walls. }\end{array}$ \\
\hline
\end{tabular}




\subsubsection{Adolf Loos and the Notion of Crime for} Ornamentation

Adolf Loos, in 1908 published his seminal essay "Ornament and Crime" where he justified this assertion and advanced that architecture should renounce ornamentation. Loos argued that ornamentations in buildings served the purpose of selfish and childish entertainment. He observed that owing to mass production, in certain countries, ornament no longer serves its cultural function, and should therefore not be seen as an expression of culture.

\subsection{Chronological and Stylistic Classification of Modern Architecture}

\subsubsection{Early Modern Architecture}

From aesthetic point of view, Modern Architecture would be classified to two main eras which are: a) Early Modern Architecture and b) High modern Architecture. Moreover, Modern Architecture in its nascent stage, which was about the 19th century, was a number of buildings with similar characteristics. Primarily this was the simplification of form and the total abhorrence of the ornament. By the 1940s these characteristics had consolidated as the International Style. This study classifies the aesthetic tendencies in early Modern Architecture into the following three categories:

a. Technical Rationalism or Rationalist tendencies:

b. Architectural Formalism or Formalism tendencies:

c. Functional tendencies:

\subsubsection{The Technical Rationalism}

Rationalism is the notion that the structure determines the form. It is the philosophy that the material of construction bespeaks architectural expression. The school accepts and promotes the employment of science theory, technology and techniques in Architecture ( $\mathrm{Nia}$ and Rahbarianyazd, 2019) while it rejects excessive décor. Rational architects used the philosophy of Rene Descartes -the father of modern philosophy (1596-1650) - and highlighted ideal proportions and geometric forms. The architecture of Étienne-Louis Boullée (1728-99) and Claude Nicholas Ledoux (1736-1806) characterize the Enlightenment rationalism, with their pure approaches to design such as including spheres, squares, geometric forms, and cylinders (Ianca, \& Georgescu, 2018).

\subsubsection{The Formalism}

Referencing his "Theory of Forms" and in particular his synthesis of Eidos ${ }^{1}$, it can be recalled that formalism started with Plato, and with Immanuel Kant's definition of the "aesthetic judgment" and his formulation regarding the sovereignty of the aesthetic object and self-sufficiency. Kant's epistemology has impacted German Formalism, and roundabout, Russian Formalism (Ianca, S \& Georgescu, 2018). Within the framework of this Formalism, the shape of the building became germane to modern aesthetic. Foremost amongst the Formalist styles in Early Modern era and their aesthetic language are shown in the table below:

1 Plato uses Eidos in some methodically different ways, sometimes meaning extension of a Form and sometimes meaning Form. 
Table 3. Aesthetic characteristics of the foremost styles of Formalism tendencies in early modern era

\begin{tabular}{|c|c|c|}
\hline & Aims/Ideas & Aesthetic Characteristics \\
\hline $\begin{array}{l}\text { Arts and } \\
\text { Movement } \\
1860-1910\end{array}$ & $\begin{array}{l}\text {-Reaction to undesirable aesthetic concerns of the } \\
\text { Industrial Revolution. } \\
\text { - Preserve individual craftsmanship, Decorative arts }\end{array}$ & $\begin{array}{l}\text {-Built of natural materials. } \\
\text {-Historicizing elements such as steep roofs, prominent } \\
\text { chimneys, cross gables, and exposed-beam ceilings. }\end{array}$ \\
\hline $\begin{array}{l}\text { Beaux } \\
\text { Architecture } \\
1885-1945\end{array}$ & $\begin{array}{l}\text {-Classicism, Classical Revival } \\
\text {-Eclectic form of Neoclassicism. } \\
\text { - Imposing scale and Classical principles. }\end{array}$ & $\begin{array}{l}\text {-Characterized by formal design, order, symmetry, } \\
\text { grandiosity } \\
\text { - Elaborate ornamentation. } \\
\text {-Triangular pediments. }\end{array}$ \\
\hline $\begin{array}{l}\text { Art Nouveau } \\
1890-1910\end{array}$ & $\begin{array}{l}\text { - Rejects academic traditions and historicism. } \\
\text { - Spread over artistic designs to everyday objects. } \\
\text {-Supported the use of exterior decoration. }\end{array}$ & $\begin{array}{l}\text {-Flowing curves based on natural forms, Asymmetric. } \\
\text {-Classic ornamentations } \\
\text { - Mosaics Stained glass and Japanese motifs. }\end{array}$ \\
\hline $\begin{array}{l}\text { Gothic Revival } \\
\text { Neo-Gothic } \\
1905-1930\end{array}$ & $\begin{array}{l}\text {-Powerful sense of height. } \\
\text { - Scholarly approach to the revival of past styles. } \\
\text {-Create an experience of the inspiring. } \\
\text { - Sense of transcendent greatness. }\end{array}$ & $\begin{array}{l}\text {-Strong vertical lines. } \\
\text {-Ribbed vaulting. } \\
\text {-Use of steep gables. }\end{array}$ \\
\hline $\begin{array}{l}\text { Expressionism } \\
1905-1925\end{array}$ & $\begin{array}{l}\text {-Protest against the academic architecture. } \\
\text {-Function follow form. } \\
\text {-Express feelings of the viewer, inner sensitivities. } \\
\text {-Included abstraction. }\end{array}$ & $\begin{array}{l}\text {-Alteration of form for an emotional effect. } \\
\text {-The reduction of realism to symbolic. } \\
\text {-Stylistic expression of inner experience. }\end{array}$ \\
\hline $\begin{array}{l}\text { Futurism } \\
1909-1945\end{array}$ & $\begin{array}{l}\text {-Highlighted the aesthetics of speed, technology and } \\
\text { change. } \\
\text { - The elements of entirely new mechanical world. } \\
\text { - Anti-historicism. }\end{array}$ & $\begin{array}{l}\text {-long dynamic lines, suggesting speed, motion, urgency } \\
\text { and lyricism. } \\
\text {-Rejected the traditional aesthetics. } \\
\text {-Glorify life based machine and motion. }\end{array}$ \\
\hline $\begin{array}{l}\text { Constructivism } \\
1914-1932\end{array}$ & $\begin{array}{l}\text { - Aesthetic and decorative function of structure. } \\
\text {-Instill the avant-garde in everyday life. } \\
\text { - Universal harmony } \\
\text { - Unification of art and life }\end{array}$ & $\begin{array}{l}\text {-Materials of steel and glass and its futuristic } \\
\text { philosophy. } \\
\text {-Sense of presence and scale. } \\
\text {-Application of 3D cubism to non-objective and abstract } \\
\text { elements. } \\
\text {-Neoplastic aesthetic. }\end{array}$ \\
\hline $\begin{array}{l}\text { De Stijl } \\
\text { 1917- } 1931\end{array}$ & $\begin{array}{l}\text {-Supporting primary colors and the purity of } \\
\text { geometrical shape. } \\
\text { - The idea of a universal language. } \\
\text { - Expressed utopian ideal of spiritual order. } \\
\text {-Using pure geometric form to achieve pure } \\
\text { abstraction. }\end{array}$ & $\begin{array}{l}\text {-Being based on the principles of "cubism". } \\
\text {-Consists of the three primary colors (yellow, red and } \\
\text { blue). } \\
\text { - The three primary values (white, black and gray). } \\
\text { - Vertical and horizontal lines, asymmetry, geometric } \\
\text { forms. } \\
\text {-Long rectangular windows, and free-floating outer } \\
\text { walls, flat roofs. }\end{array}$ \\
\hline $\begin{array}{l}\text { Art Deco } \\
1925-1945\end{array}$ & $\begin{array}{l}\text { - Reaction to the sensuousness and flowing lines of the } \\
\text { previous of Art Nouveau and Beaux-Arts styles. }\end{array}$ & $\begin{array}{l}\text {-Zig-zags, strong lines, repeating geometric patterns and } \\
\text { symbolism. } \\
\text {-Symmetry, simple composition, rectilinear rather than } \\
\text { curvilinear shapes, and lavish ornamentation. } \\
\text {-Stucco, concrete block, glazed brick, smooth-faced } \\
\text { stone. }\end{array}$ \\
\hline $\begin{array}{l}\text { Art Moderne } \\
\text { Machine } \\
\text { Architecture } \\
1935-1950\end{array}$ & $\begin{array}{l}\text { - Represents the last phase of Art Deco } \\
\text { - Became the prevalent style of commercial, public, and } \\
\text { domestic architecture. } \\
\text { - Machine aesthetic focused on mass production. }\end{array}$ & $\begin{array}{l}\text {-Glass blocks for windows and aluminum or stainless } \\
\text { steel. } \\
\text { - Asymmetrical facades, flat Roof and horizontal } \\
\text { emphasis. } \\
\text {-Minimal decoration and Speed and movement. } \\
\text { - Corner windows, Rounded edges, Curved canopies. }\end{array}$ \\
\hline
\end{tabular}




\subsubsection{Functionalism}

Striving for balance between buildings aesthetic and functionality came to forefront with Viollet-le-Duc in the in the second half of $20^{\text {th }}$ century. This was followed up by $L$. Sullivan, whose aphorism "the form follows the function" became peculiar with principles of functionalism in the early Modern era. Functionalism brings to mind the selflessness of the space (mostly in office and industrial buildings) in which case, a space dedicated to a particular function can be reversed and used otherwise. In other words, the space becomes multi-functional. Its main aesthetic features are typically a reflection of the novel technologies available for construction and execution and the availability of new construction materials which include glass, concrete, plastics, aluminum and steel for the purpose. In modern period, due to the essence of the era, three main "schools" of functionalist architecture which are the "Bauhaus School" and "Chicago School" and Prier school have been highlighted.

\subsection{Bauhaus, School}

Bauhaus, a school of Arts and Craft, was pioneered by Walter Gropius in Germany. The school, which was founded in 1919, believed in the unity of Arts, attempted to harmonize crafts with pure arts and stood for a synthesis of the arts, ranging from the furniture details to the level of urban organization (Periton, 2011; Saletnik \& Schuldenfrei, 2009; Siebenbrodt, 2009). Bauhaus forerun standardization by initiating prefabricated elements for building, and thereby redefined the aesthetics of industrial product and mass production. Influenced by the art philosophy, the school favors buildings innately endowed with sculptural presence; howbeit in addition, it sets function before the form. Modern buildings designed in the Bauhaus are light structured, constructed in glass, steel and concrete with stained glass facades.

\subsection{Chicago's School}

Following the Chicago Fire of 1871, which left most of the urban core area ruined, the need for extensive rebuilding while at the same time adopting a much higher fire safety precaution became imperative. This is especially important because at that point in time, the population of Chicago was rapidly tending to a million. The rising costs of real estate and the introduction of elevators in Chicago following the urban renewal had also encouraged vertical building construction which impacted emphasis on vertical aesthetic since then.

\subsection{Prairie School}

The protagonists of the Prairie School were John Ruskin, William Morris amongst others. The school emerged as the result of growing sympathy with the design aesthetics and ideals of the Arts and Crafts Movement which began in the late 19th century in England. The Prairie School detested the current wave of mass production in industrial assembly lines and justified this by claiming that it dehumanized workers and that the process created inferior materials. They reacted by devoting themselves to handcrafting and the craftsman societies (Koning and Eizenberg, 1981). The emphasis of the Prairie school is the following:

- Horizontal expansion of the building as opposed to vertical. Prairie houses were typically two-story buildings with single-story wings. They emphasized horizontality using ribbon windows, suppressed, heavy-set chimneys, gently sloping roofs, and overhangs and horizontal lines.

The following table illustrates the main aesthetic characteristics of functionalism schools of modern architecture.

Table 4. Three main schools developed based on the notion of Functionalism.

\begin{tabular}{|c|c|c|c|}
\hline & Basic ideas & Main concerns & Architectural Characteristics \\
\hline $\begin{array}{l}\text { Chicago } \\
\text { School } \\
1875-1925\end{array}$ & $\begin{array}{l}\text {-Pioneer in the expansion of Modern } \\
\text { Architecture. } \\
\text {-Emphasized on the vertical aesthetic. }\end{array}$ & $\begin{array}{l}\text { - Invention of elevators had } \\
\text { encouraged vertical building } \\
\text { construction. }\end{array}$ & $\begin{array}{l}\text { - Aesthetic implication of steel and Iron. } \\
\text {-High rise buildings. } \\
\text { - Much severer degree of fire safety. }\end{array}$ \\
\hline $\begin{array}{l}\text { Bauhaus } \\
\text { school } \\
1919-1933\end{array}$ & $\begin{array}{l}\text {-Embraced the aesthetic theory of } \\
\text { functionalism. } \\
\text { - Fears about art's loss of purpose in } \\
\text { society. }\end{array}$ & $\begin{array}{l}\text {-"Form follows function." } \\
\text {-The aesthetics of machine. } \\
\text { - Simple forms }\end{array}$ & $\begin{array}{l}\text { - Order, regularity, and the sense of space, } \\
\text { rather than mass predominated. } \\
\text {-Free-plan interiors. } \\
\text {-Use of concrete, glass and steel; stark } \\
\text { white cubes. }\end{array}$ \\
\hline $\begin{array}{l}\text { Prairie } \\
\text { School } \\
1905-1925\end{array}$ & $\begin{array}{l}\text { - Sympathy with the ideals and design } \\
\text { aesthetics of the Arts and Crafts } \\
\text { Movement. } \\
\text { - Against the new assembly line, mass } \\
\text { production. }\end{array}$ & $\begin{array}{l}\text {-Emphasis on horizontal lines. } \\
\text {-Low proportions. } \\
\text {-Gently sloping roofs and } \\
\text { sheltering overhangs. } \\
\text {-Visual expression of natural } \\
\text { materials. }\end{array}$ & $\begin{array}{l}\text {-The emphasis is on the horizontal } \\
\text { expansion of the building. } \\
\text {-Generally two-story building. } \\
\text { - The idea of abandoning small, boxy rooms } \\
\text { in favor of a more open, integrated interior } \\
\text { space. } \\
\text { - Suppressed, heavy-set chimneys, Ribbon } \\
\text { windows, overhangs and gently sloping } \\
\text { roofs. }\end{array}$ \\
\hline
\end{tabular}




\subsubsection{Late Modernism 1945-1972}

Further assessment of the aesthetic nature of Modern Architecture revealed another important classification which has been described as Late Modern or Late Modernism. Late Modern Architecture was most fashionable between the period after World War II to early 1970s. Although, its ideals are rectangular forms just as the Modern Movement, nonetheless, Late Modern architects conceive that buildings are not merely simple set of volumes, but masterpiece of sculptural articulations. This is acceptable even when these sculptural forms are simply the result of structural engineering innovations. This study classifies the aesthetic characteristics of Late Modern Architecture in four main categories which are International style, Organic Architecture, Brutalism and Minimalism.

\subsubsection{The International Style (1920-1965)}

The International style was a reaction against the historicist styles and Art Nouveau of the $19^{\text {th }}$ and $20^{\text {th }}$ centuries. It is a clean break from tradition. As it has already been mentioned, the style came to limelight in the United States amid the Nazi prejudice in Germany and the Bauhaus initiated the ideas that culminated it. In the US, the style was associated with upscale buildings. Characteristic of the International style is the emphasis on austerity, clean lines, clinical white colors, bald facades and total rejection of ornaments. The hallmark of the style is its emphasis on volumes rather than mass, so much so that it portrays an aura of lightness and weightlessness using thin curtain walls, open plan spaces, machine aesthetics, up-to-minute innovations in building technology, prefabrications, and the honest use of materials (Nia, H., \& Suleiman, 2018 Colquhoun, 1962). The style supports that buildings should be designed to be rational and scientific in their organization which dictated the search for honesty, economy and utility that meets society's new needs while at the same time appealing to the aesthetic taste. Glass and steel, in combination with usually less visible reinforced concrete, are the characteristic materials of construction. Conventionally, roofs are flat and construction is normally of steel frame or reinforced concrete tactically hidden to portray light weight thin fabrication which remained its highpoint.

\subsubsection{Brutalism}

Brutalism was an architectural movement that aimed to redress the Modern Movement. It was also a reaction against the Modern Movement claiming that its scale is frivolous and as a result does not serve the purpose for Architecture. It also suggested that Modern Movement is deficient in its utilitarian functions. Reyner Banham, an architectural critic, was first to coin out the term "Brutalism" to express concern over this in his 1966 publication "The New Brutalism: Ethic or Aesthetic?" Consequently, the movement defined its high points with grandeur, monumentality and heroism and advanced that the Modern Movement should embrace it (Lozanovskam, 2015). Although, Reyner Banham expressed scholarly concern, the French architect, Le Corbusier demonstrated the praxis. Thus, the idea began in France. Brutalism is an architectural philosophy that advocated for a more formal expression where function and materials were honest and exposed. Its strong points are massive use of concrete and repeated angles. According to Royal Institute of British Architects (RIBA), the foremost aesthetic characteristic of Brutalist buildings are:

- Unusual shapes

- Heavy looking materials

- Relatively Small windows

- Massive forms

- Rough unfinished surfaces.

While a high point of the Brutalist Movement on one hand is the continuous repetition of architectural features to generate modules of activity areas which are distinctly recognizable, on the other, concrete is used with immaculate honesty and in its unaffected form. These are a far departure from the earlier delicate and flowery elite Beaux-Arts architectural style. Indeed, the facades of casted concrete were retained without cosmetic coatings. Building materials comprise gabions, glass, brick, steel, and rough-hewn stone. It is imperative here to point out that not all buildings exhibiting an exposed concrete exterior are Brutalist. They may belong to one of a range of architectural styles including the International Style, Constructivism, Postmodernism, Expressionism and De-Constructivism.

\subsubsection{Organic Architecture (1908 Onward)}

Organic architecture is a philosophy that a building and its environment are altogether one and the same. Frank Lloyd Wright developed the philosophy of Organic Architecture to conceptualize the notion that a building evolves from its natural environment. Despite this, it is further expected that there must be harmony between all the parts of the building and that the building must altogether constitute a united whole. The highpoints of Organic Architecture are reflected in the fact that the building is an organism and as such every part of the building - from the fenestrations to the walls, the space to the furniture that fill it - must be true and systemically related to each other. In this way, Organic Architecture reflects the symbiotic ordering systems of nature (Wright, 1954).

From Wright's perspective, organic architecture is a mimic of the nature around us in buildings. Wright asserted that buildings should correspond to time and place and should intricately interweave with its site so much so that the building should "grow naturally" from the site. This aside, Wright was also convinced that all the parts of the building must relate in tandem constituting as a result, an organism. He asserted the use of natural design elements such as water, plants, spacious interiors, natural lighting, and natural building materials to epitomize Organic Architecture (Zevi, 1950). Contrariwise, buildings according to this view should discountenance artificial lighting and building materials. Within this ideological framework, colour choices are also 
considered imperative and are usually yellows, oranges, and browns reflecting the environment. Wrights ideology of design has crystalized over the years as "Organic" and has been identified as such. Some of the highpoints of this ideology are the following:

- Using natural colors.

- $\quad$ Providing a place for natural greenery.

- One integrating dominant form.

- Revealing the nature of materials.

- The idea that a building should grow from its site.

- Opening up spaces.

Overall, from aesthetic point of view, the term Organic Architecture typifies a symbiotic association between the building and environment. The building cannot be detached from the environment from which it "grows", while the building itself relates with itself in organized rhythm and relationships.

\subsubsection{Minimalism (1960s- 1970s)}

Minimalism commenced following the aftermath of post-World War II Western Arts. It was most conspicuous with American visual arts of the 1960s and early 1970s. This notwithstanding, De Stijl and traditional Japanese design were generally accepted as forerunners of the minimalist movement. In Architecture, minimalism is a reductive ideology preying on Modernism. It has also been seen as a reactionary ideology pinning against abstract expressionism and a transition to post-minimal arts. Minimalist architecture is an attempt to strip-off all "non-essentials" until simplicity is achieved (Cerver, 1997). This does not necessarily mean the total absence of ornamentation but it indicated a condition where nothing else can be removed to improve the quality of design (Bertoni, 2002).

Within this ideology, design elements project the sense of simplicity. Typically, open-plan spatial arrangements, harmonious colors, basic geometric shapes, elements without decoration, natural textures, clean finishes, neat and straight components, large windows and satisfying negative spaces, flat or nearly flat roofs, simple materials, repetitions are used to achieve simplicity. Minimalist architects are not exclusively concerned with the physical aesthetic qualities of the buildings but with spiritual aesthetic and the invisible as well. They do so by hearing from the building and paying attention to space, details, nature, people and materials (Bertoni, 2002).

The following table illustrates the main aesthetic characteristics of four main styles in the Late Modern architecture.

Table 5. Four main categories of the late modern architecture.

\begin{tabular}{|c|c|c|c|}
\hline & Idea & $\begin{array}{l}\text { Major } \\
\text { Characteristic }\end{array}$ & Architectural Characteristics \\
\hline $\begin{array}{l}\text { International } \\
\text { style }\end{array}$ & $\begin{array}{l}\text {-Response against historicist } \\
\text { styles of the 19th and 20th } \\
\text { centuries. } \\
\text {-Optimum use of technology and } \\
\text { modern materials. }\end{array}$ & $\begin{array}{l}\text { - Curtain walls of glass or } \\
\text { prefabricated parts. } \\
\text { - Rational organization of a plan. } \\
\text {-Open interior spaces. } \\
\text { - Volume (usually rectangular) }\end{array}$ & $\begin{array}{l}\text {-Clear articulation of the grid frame. } \\
\text { - Precise regularity of a modular } \\
\text { pattern. } \\
\text {-Rectilinear forms. } \\
\text { - Glass and steel. }\end{array}$ \\
\hline $\begin{array}{l}\text { Organic } \\
\text { Architecture }\end{array}$ & $\begin{array}{l}\text { - Promotes harmony between } \\
\text { natural world and human } \\
\text { habitation. } \\
\text {-Building should develop out of } \\
\text { its natural surroundings. }\end{array}$ & $\begin{array}{l}\text {-Be inspired by nature and be } \\
\text { sustainable, healthy, conserving, and } \\
\text { diverse. } \\
\text {-Exist in the "continuous present" and } \\
\text { "begin again". }\end{array}$ & $\begin{array}{l}\text {-Prairie school style of creating } \\
\text { residential homes. } \\
\text {-Harmony with the nature. } \\
\text {-horizontal lines. } \\
\text {-"Grow out of the site". }\end{array}$ \\
\hline Brutalism & $\begin{array}{l}\text {-To reveal the basic nature of its } \\
\text { construction. } \\
\text { - Exposure of the building's } \\
\text { functions. } \\
\text { - To redirect Modern Architecture } \\
\text { toward a more monumental form. } \\
\text { - Associated with a collective } \\
\text { utopian ideology. }\end{array}$ & $\begin{array}{l}\text {-Rough unfinished surfaces } \\
\text {-Unusual shapes } \\
\text {-Heavy-looking materials } \\
\text {-Massive forms } \\
\text { - Extensive use of raw concrete. } \\
\text {-Concrete are made to reveal the basic } \\
\text { nature of its construction. }\end{array}$ & $\begin{array}{l}\text {-Repeated modular elements. } \\
\text { - Specific functional zones. } \\
\text { - Usually formed with repeated } \\
\text { modular elements. } \\
\text { - Nclude brick, glass, steel, } \\
\text { rough-hewn stone, rough-hewn stone } \\
\text { and gabions. } \\
\text { - Relatively small windows. }\end{array}$ \\
\hline Minimalism & $\begin{array}{l}\text {-Response against abstract } \\
\text { expressionism. } \\
\text {-Simplicity convey the ideas of } \\
\text { freedom. }\end{array}$ & $\begin{array}{l}\text { - Traditional Japanese design and De } \\
\text { Stijl are predecessors. } \\
\text {-Basic geometric shapes. } \\
\text {-Natural textures, open-plan spatial } \\
\text { arrangements, clean finishes. } \\
\text {-Simplicity in form and function. }\end{array}$ & $\begin{array}{l}\text {-Uncomplicated cladding and wall } \\
\text { finishes. } \\
\text {-Clean, open, light-filled spaces. } \\
\text {-Simple detailing devoid of } \\
\text { decoration } \\
\text { - Simple materials and large } \\
\text { windows. } \\
\text {-Harmonious colours, Flat or nearly } \\
\text { flat roofs. }\end{array}$ \\
\hline
\end{tabular}




\section{Discussion}

Throughout the history of Modern Architecture, there were some fluctuations on aesthetic understanding and the philosophy of aesthetic construction. These resulted in different views in the aesthetic understanding of Modern Architecture which has led to different architectural styles. As was earlier clarified, Modern Architecture, by the ideas it conveyed in its major philosophies such as the house is a machine for living, form follows function and ornamentations is crime aimed at benefiting from the technological assets resulting from the industrial revolution. This is in spite of the fact that Modern Architecture derived its negative reputation by rejecting traditional styles. This study also highlighted some architectural styles of the modern era such as the Arts and Crafts movement, Beaux Arts Architecture, Art Nouveau and the Gothic Revival which seems to logically adopt modern technologies in such a way that their local authenticity can still be seen.

As soon as Futurism and expressionism emerged as architectural methods of construction, it became obvious that this was a significant milestone in the aesthetic understanding of the Modern Architecture. Distortion of form for an emotional effect (which was the Expressionism philosophy of design and the futurism emphasis on the beauty of speed and technology) opened new vistas in the history of Modern Architecture. Thereafter, famous architects (depending on the era) such as Le Corbusier, Walter Gropious, Adolf Loos and Mies van der Rohe have followed the same ideology. The Rationalist, Formalism and Functionalist tendencies were three main factors which were developed from the modernism philosophy of construction.

The study revealed that between 1945-1972 there was another milestone landmarking the history of Modern Architecture; which was Late Modernism. This era, which began after the Second World War, can be classified from an aesthetic point of vew into four main styles. Apart from International style which was the continous logical development of Bauhaus functionalist ideology, the other architectural styles were Brutalism, Organic Architecture and Minimalism; all of which attempted to develop specific aesthetic language to fit modernistic buildings. Overall, Figure 1 below illustrates the chronological development of aesthetic progress in Modern Architecture.

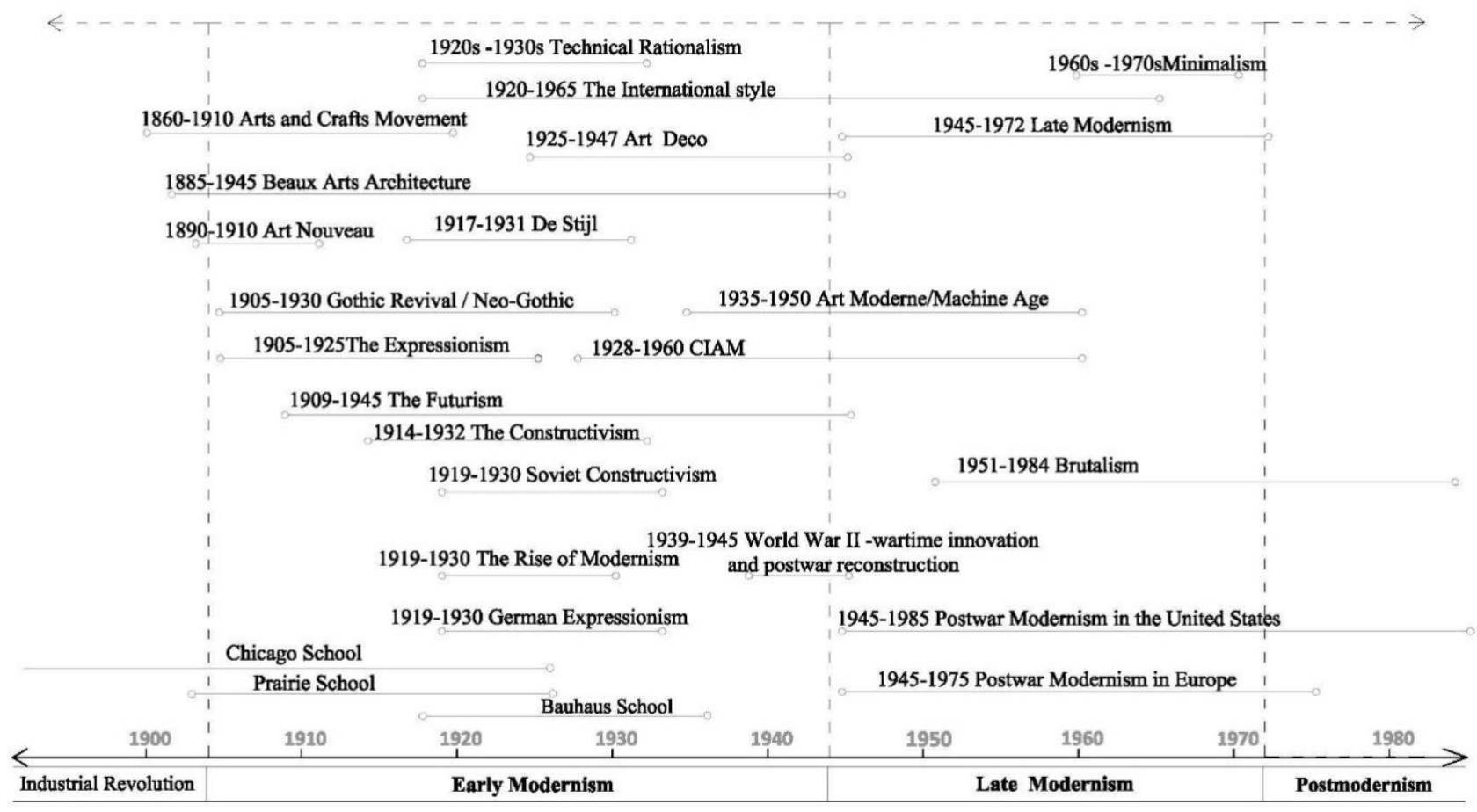

Figure 1. Chronological development of aesthetic progress in Modern Architecture 
There have also been several attempts to justify the logic of modernistic ideology from the architectural points of view. This study however revealed that apart from logical aesthetic applications, there were many other factors which led to its failure. As was previously stated, removing ornamentation and conceiving architecture as machine for living was the main and preliminary factor why people's aesthetic curiosity were never satisfied. In this regard, Charles Jencks pointed out that the destruction of the notorious Pruitt-Igoe ${ }^{2}$ on July 15, 1972 was in fact "death of Modern Architecture". The building was designed premising on the ideals of CIAM (Congress Internationaux D' architecture Moderne). It epitomizes the beliefs of Modern Architecture in which "good form was to lead to good context (Jencks, 1987; Guzer and Abdi, 2006). Pruitt-Igoe was destroyed owing to vandalization and ultimate rejection by users. In fact, despite enormous spending for maintenance and restoration, the problems with it persisted. Taking its destruction event as a symbol, Charles Jencks asserted the death of Modernism and the beginning of a new period as Post-Modern era. Aesthetic characteristics of postmodernism are other notions that need to be considered for future study.

\section{Conclusions}

The study revealed that progressive capitalism and the technological process constitutes the two major reasons for the emergence of Modern Architecture. The study further revealed that the emerging industrialization and the concomitant machine technology brought along with it new possibilities in construction, and in the advancement of new materials, logic and standardization to redirect the course of architectural aesthetics. Thus, it has been put forward that, such attributes as function, standard, efficiency, and self-referential designs are the highpoints of Modern Architecture. It also became clearer from this study that one of the main purposes of Modern Architecture was to set the criteria for architecture based on performance and function to achieve comfort, hygiene, quality of life and health.

This study concludes that the Le Corbusier's maxim: "the house is a machine for living" promoted utility, efficiency, economy, accuracy, functionality, technology, and enhanced the love for simple building aesthetics.

The study also revealed that the adoption of standardization in Modern Architecture is significant because it enhanced order, planning and became a foundation for reviewing architectural designs scientifically. It is therefore obvious that it is the foothold upon which good architecture had emerged. Considering this fact, it was highlighted that the major factor which led to the failure of Modern Architecture was its relegation of cultural references. Ignoring cultural values and its symbolic ornamentation for the machine as the standardized method for architectural designing, resulted in the lack of sense of place and lack of place attachment. These have been considered the most important non-aesthetic factor in the failure of Modern Architecture. Overall, this study points out that the interrelation between the quality of life in the modern era and Modern Architecture is an area that needs further studies to answer the question on why Modern Architecture failed to improve the aesthetic quality of life aside from its own unique approaches.

\section{Acknowledgements}

This research did not receive any specific grant from funding agencies in the public, commercial, or not-for-profit sectors.

\section{Conflict of Interests}

The authors declare no conflict of interest.

\section{REFERENCES}

[1] Ali, F. (2018). The Influence of Le Corbusier On the emergence of the Aesthetic Values in the Modern Architecture of Cyprus. Journal of Contemporary Urban Affairs, 2(1), 1-12.https://doi.org/10.25034/ijcua.2017.365 1

[2] Amiri, N. (2016). Modernism and Postmodernism in Architecture, an Emphasis on the Characteristics, Similarities and Differences. Journal of Design, Art and Communication - Special Edition. 6(1), 1626 - 1634. https://doi.org/10.7456/1060agse/044

[3] Ando, T. (1993). In Dialoque with Geometry: The Creation of Landscape. GA Architect, 12(1), pp. 5-24.

[4] Ando, T. (2002). Seven interviews with Tadao Ando. Surrey, Modern Art Museum of Forth Worth. Third Millennium Pub: USA

[5] Arenibafo, F. (2017). The Transformation of Aesthetics in Architecture from Traditional to Modern Architecture: A case study of the Yoruba (southwestern) region of Nigeria. Journal of Contemporary Urban Affairs, 1(1), 35-44. https://doi.org/10.25034/1761.1(1)35-44

[6] Aziz Amen, M. (2017). The inspiration of Bauhaus principles on the modern housing in Cyprus. Journal of Contemporary Urban Affairs, 1(2), 21-32. https://doi.org/1 $0.25034 /$ ijcua.2017.3645

[7] Bertoni, F. (2002). Minimalist Architecture, edited by Franco Cantini, translated from the Italian by Lucinda Byatt and from the Spanish by Paul Hammond. Basel, Boston, and Berlin: Birkhäuser. 
[8] Cerver, F. A. (1997). The Architecture of Minimalism. New York: Arco.

[9] Colquhoun, A. (1962). The Modern Movement in Architecture, The British Journal of Aesthetics, 2(1) 59-65, https://doi.org/10.1093/bjaesthetics/2.1.59

[10] Evenson, N. (1969). Le Corbusier: The machine and the grand design, London: Studio Vista

[11] Frampton, K and Futagawa, Y. (1983). Modern Architecture 1851-1945. New York: Rizzoli

[12] Frampton, K. (1992). Modern Architecture, a critical history. London:Thames and Hudson.

[13] Guzer, C. Abdi. (2006). Architecture as a Cultural Continuity and Discontinuity: An alternative understanding of contextual Sensuality. III Mediterranean Congress of Aesthetics. Portorose, Slovenia.

[14] Ianca, S \& Georgescu, M. (2016). Politehnica "University of Timisoara. Architecture Notes. Politehnica "University of Timisoara. Retrieved from: https://lovedoc.org/the-philosophy-of-money.html?utm_so urce $=$ architecture-notes-pdf .

[15] Jaff, A. A. M. A., Shabander, M. S. A., \& Bala, H. A. (2017). Modernity and Tradition in the Context of Erbil Old Town. American Journal of Civil Engineering and Architecture, 5(6), 217-224. https://doi.org/10.12691/ajcea-5-6-1

[16] Saletnik, J \& Schuldenfrei, R. (2009). Bauhaus Construct. New York: Routledge.

[17] Jencks, C. (1987). The Language of Post-Modern Architecture. New York: Rizzoli Academy Editions.

[18] Koning H. and J. Eizenberg, The language of the prairie: Frank Loyd's Wright prairie houses. In Environment and Planning B, 8 (3), 295-323, 1981. https://doi.org/10.1068/b 080295

[19] Le Corbusier. (1986). Towards a new architecture. Dover Publication: New York.

[20] Lozanovska, M. (2015). Brutalism, Metabolism and its American Parallel. Fabrications, 25(2), 152-175. doi: 10.10 80/10331867.2015.1032482

[21] Nia, H., \& Suleiman, Y. (2018). Aesthetics of Space Organization: Lessons from Traditional European Cities. Journal of Contemporary Urban Affairs, 2(1), 66-75. https://doi.org/10.25034/ijcua. 2018.3659

[22] Nesbitt, K., ed. (1996). Theorizing A New Agenda for Architecture: An Anthology of Architectural Theory 1965 1995. New York, Princeton Architectural Press.https://boo ks.google.com.tr/books/about/Theorizing a new agenda for_architecture.html?id=u7tPAAAAMAA J\&redir_esc $=\bar{y}$

[23] Norberg-Schulz, C. (1988). Roots of Modern Architecture, Tokyo, A.D.A. Edita: Tokyo.

[24] Periton, D. (2011). The Bauhaus as cultural paradigm. Volume 1 (3), 189-205.https://doi.org/10.1080/136023696 374640

[25] Rahbarianyazd, R and Nia, A. H. (2019). Stylistic Approach to Contemporary Architecture. Alany Belediyesi: Turkey

[26] Salvo, S. (2015). Conservation and modern architecture.
Fortune and misfortune of the School of Mathematics at Rome University (G. Ponti, 1932-1935). Frontiers of Architectural Research, 4(3), 186-201. https://doi.org/10.1 016/j.foar.2015.03.004

[27] Siebenbrodt, M. (2009). Bauhaus: A Conceptual Model. Berlin: Hatje Cantz.

[28] Wright, F.L. (1954). The Natural House. New York: Horizon Press.

[29] Zevi, B. (1950). Towards an Organic Architecture. London: Faber and Faber. 